Janusz Nawrot ${ }^{1}$

Adam Mickiewicz University in Poznań

Faculty of Theology

\title{
The Seizure of the Throne by Demetrius I Soter (1 Macc 7:1-4): Theological Interpretation of a Historical Event
}

The First Book of Maccabees was doubtlessly written on the pattern of earlier deuterocanonical books where history is combined with a theological message. There would be nothing out of ordinary in such a presentation of Israel's history were it not for the fact that the biblical text in question belongs to a group of those ones which, from a historical perspective, describe a geographical event that is far away from the scope of influence of the Jewish insurgents but one which is closely linked to the history of the chosen people. This event has a strong impact on the events to come as a result of the political-religious situation of the Jews. What is particularly worthy of investigation is, on the one hand, the accuracy of historical facts presented by the inspired author and, on the other hand, the theological conception that remains unchanged by this accuracy. This theological conception is always, as is the case in every biblical book, of primary importance. This way the history of peoples, kingdoms and societies is shown as part of God's magnificent plans regarding all the participants of different actions, including leading characters and those who remain in the background. The short passage 1 Macc 7:1-4 shows how the hagiographer, who had the theological intention at hand, consciously accentuates different parts of the description, chooses appropriate syntax and vocabulary in order to show the action of God Himself as He stands behind human activities and decisively influences their direction.

${ }^{1}$ Janusz Nawrot - Professor of Theology, is the Head of the Department of Biblical Sciences at the Faculty of Theology at Adam Mickiewicz University in Poznań, e-mail: jannaw@amu.edu. pl, ORCID: 0000-0002-2498-5081.

PST 40, 2021: 7-32. (C) The Author(s), Adam Mickiewicz University Press, 2021.

Open Access article, distributed under the terms of the CC licence (BY-NC-ND, https://creativecommons.org/licenses/by-nc-nd/4.0/). 
Succession in monarchies impacts both their own societies and the societies of the neighboring countries, yet in the case of the chosen people - about which the author still writes - this impact is largely modified by the God of covenant. The biblical description of such a succession presents an interaction between what people do and what God does through them as $\mathrm{He}$ is the one and ultimate ruler of everything that happens in the arena of the whole world. It is thus possible to capture the historical dimension of the occurring events and its theological meaning. The coherence of the whole account is an argument in favor of the conviction that each word used by the author is intentional and derives from God's inspiration. This paper aims to show this interconnection of history and faith, and consequently, the divine inspiration of the whole biblical book. This book is not merely an Old Testament Apocrypha, but a full-fledged biblical book.

The article intends to deepen the theological view of the historical facts recorded by the hagiographer which were noted in the second part of my commentary on the First Book of Maccabees. Due to the enormous amount of the accumulated material, it was not possible to thoroughly analyze all the events described in this book. In the introduction to this commentary, I have already noted that the vast majority of studies which deal with the topic of the Maccabean revolt avoid theological analysis of facts, treating the book almost exclusively as a historical material. I have listed a large number of these studies and articles in the bibliography in my commentary ${ }^{2}$. Neither of them deals with the opening verses of chapter 7 in detail and from the theological perspective. One of the reasons for this negligence of the theological dimension of the story may be that apart from the Catholic and Orthodox Church, deuterocanonical books (as 1,2 Macc) are not included in the inspired books of the Old Testament (and are considered apocrypha) in the Jewish and Protestant tradition. Using the research I have already done in my commentary on the text of 1 Macc 7: 1-4, I will try to show in detail how the inspired author interprets in the theological way the facts which were also recounted by ancient historians. As it is written in Polish, getting acquainted with the exegesis of these verses by the method of intertextual analysis may now be beneficial for the English reader. Previous papers were written in Polish, thus this paper will be useful for the English reader who is interested in the intertextual analysis of the text. The paper has been divided into two main sections; the first one presents a widely understood historical background of events described in 1 Macc 7:1-4, while the second one discusses their theological dimension.

2 J. Nawrot, Pierwsza Księga Machabejska. Rozdziaty 6,17-16,24, Nowy Komentarz Biblijny - Stary Testament XIV/II, Częstochowa 2020, pp. 1150, 1161-1169. 


\section{Historical Context of the Discussed Events}

In the analyzed passage of 1 Macc 7:1-4 the author does not present a detailed account of the current life situation of the new king. However, the inspired author introduces the king as an important figure in the ongoing events and in the subsequent phase of the insurgents' fight for religious freedom of their people. It could be suspected that readers of the hagiographer's account still remembered Demetrius I, for which reason it was unnecessary to explain all the aspects of occurring events; many of these events were out of scope of the Jewish influences and were of little importance to the subsequent course of action of the whole insurrection. It is important, however, to note that the author's account goes very well in line with the historical facts although it is very brief. This is confirmed particularly by accounts of various ancient historians.

\section{Demetrius I as a Political Hostage}

The son of the deceased king Seleucus IV Philopator and the nephew of Antiochus IV Epiphanes took the royal title of "Soter", that is "Savior". He is another very important character in the Maccabean battle with the royal power. Polybius notes in his Histories 31,2 that during his childhood years Demetrius became a political hostage of the Roman senate which demanded that he should remain in the capital of the empire - this was to guarantee the realization of the resolutions contained in the peace Treaty of Apamea ${ }^{3}$ by the Seleucids.

Demetrius, the son of Seleucus, had now been held in hostage at Rome for many years, and it had long been thought that his detention was unjust, since he had been given by his father Seleucus as a hostage for his own good faith, and now that Antiochus had succeeded to the crown he should not be required to serve as hostage for the children of Seleucus. He had, however, taken no steps previously, chiefly owing to want of capacity, as he was still a boy (31,2,1-4; LCL 161: 183).

${ }^{3}$ This peace was made in 188 BC. It followed the Battle of Magnesia defeated two years earlier and recounted by Livy in the History of Rome 37:39-42. According to the treaty, Antiochus III was forced to release twenty hostages to Rome aged 18-45 who were to be exchanged every three years (Polybius, Histories 21:42,22). Examples of hostage exchanges in times of the Roman Empire are noted also by A. C. Johnson, P. R. Coleman-Norton, F. C. Bourne, Ancient Roman Statutes: A Translation with Introduction, Commentary, Glossary and Index, Austin 1961, p. 26; G. Long, The Decline of the Roman Republic, Vol. 3, London 1869, p. 159. 
A similar account was also given by Marcus Junianus Justinus in his work the Epitome, although here the description of the family relations of Demetrius contains an error:

Demetrius, who was a hostage at Rome, and who had heard of the death of his brother, went to the senate, and said that "he had come to Rome as a hostage while his brother was alive, but that now he was dead, he did not know for whom he was a hostage". It was therefore reasonable, he added, "that he should be released to claim the throne, which, as he had conceded it to his elder brother by the law of nations, now of right belonged to himself, as he was superior to the orphan in age" $(34,3)^{4}$.

The shortest account can be found in Periochae by Titus Livius who lived on the turn of the epochs and who doubtlessly utilized the older chronicles. He writes about the later actions of Demetrius as follows: "Demetrius, the son of Seleucus, who had been a hostage at Rome and had sailed away secretly, because he was not released. Demetrius was received as king (46,12; LCL 404: 13)"5.

So after the death of Antiochus III the Great in 187 BC, the Syrian throne was taken by his older son - Seleucus IV Philopator ${ }^{6}$. This situation resulted in Rome's demand for a hostage exchange; the oldest son of the current ruler Demetrius - arrived in the empire's capital instead of the royal brother - Antiochus IV. He was supposed to guarantee that the resolutions of the Treaty of Apamea be fulfilled ${ }^{7}$. According to Polybius and Appian of Alexandria, this hostage exchange took place around $175 \mathrm{BC}$, shortly before the death of Seleucus IV Philopator, as that year his son Antiochus became his direct successor but was unseated by his uncle five years later ${ }^{8}$. Numerous ancient historical texts confirm the custom of taking hostages from defeated adversaries by the Roman republic. Undoubtedly, the main reason for this practice was the requirement to respect treaties sealed between the republic and the defeated adversary mostly in some sort of military confrontation. What was equally important was to familiarize hostages with the norms of how the republic worked and by which principles it

${ }^{4}$ Quoted from: http://www.attalus.org/translate/justin5.html [accessed on 10.07.2021].

${ }^{5}$ Livy, Julius Obsequens, History of Rome, Vol. 14: Summaries. Fragments. Julius Obsequens. General Index, trans. A. C. Schlesinger, Loeb Classical Library 404, Cambridge (MA) 1959, p. 13.

6 J. E. Morby, Dynastie świata. Przewodnik chronologiczny i genealogiczny, tł. M. Rusinek, Kraków 1998, p. 69.

7 J. Nawrot, Kryzys religijny w Judei za Antiocha IV Epifanesa. Teologia historii w 1 Mch 1,1-2,26, Poznań 2012, p. 38.

${ }^{8}$ A. Ziółkowski, Historia Powszechna. Starożytność, Warszawa 2011, p. 611. 
operated. It was also important for a hostage to recognize the republic's hospitality and their cost of living so as to evoke gratitude and, consequently, loyalty toward the Romans.

Polybius also notes that hostages, who were most often children of local notables, were chosen by Rome and were aged between 12 and 40. They were kept captive for a few years and in case some of them died, they were to be replaced by others $(21,32 \mathrm{a}, 10)^{9}$. Most frequently, such hostages were kept captive off their own land, far away from the political or military confrontations or the area where the family of the captive had some sort of influence. This was to prevent possible retaliation from the aggrieved and to disable the captives from escaping either on their own or with the help of their affiliates. In the long run, the superiority of one's own culture and politics was shown so that captives could become accustomed to them and introduce these elements in their own country when they got back home. In some cases, it was also possible to take advantage of personal relations between a juvenile hostage and their guardian as the former could feel indebted to the latter. All of the above factors helped to Romanize foreign hostages, which was an important factor or even an aim of the policies implemented by the senate toward rival empires. In the case of Demetrius, who was a highborn royal son, the senate probably made an exception and allowed him to remain in the capital similar to Antiochus IV Epiphanes, who had been given a special house funded out of public money. Demetrius was later allowed to settle in it. This means that the senate took official responsibility for the quality of hostages' accommodation in the republic. There is vast evidence that Demetrius had significant financial resources and a limited number of his own acquaintances, so he was not isolated. Perhaps he was subject to some sort of contact and correspondence surveillance as he was a hostage from a country that had caused trouble to the republic. Relative ease of escape indicates that he moved quite a lot and met with his chosen friends. Such conclusions can be drawn from the speech to the senators cited above.

\section{Escape from Rome}

Accounts of ancient historians, such as Appian of Alexandria and Polybius, explain why escape from Rome was successful. The former speaks laconically in the Roman History about the senate's decision after the death of Antiochus IV who had orphaned a juvenile Antiochus V Eupator:

9 This is a note of a sample political treatise between the republic and the members of the Aetolian League in 189 BC, inter alia M. Dillon, L. Garland, Ancient Rome: A Sourcebook, Abingdon 2005, p. 255. 
Demetrius, the son of Seleucus, nephew of Antiochus Epiphanes, grandson of Antiochus the Great and first cousin of the young boy, was still a hostage in Rome, and now in his twenty-third year, when he asked to be installed on the throne, to which he maintained he had a better claim; the Romans refused. They thought it would be more advantageous to them if an immature boy ruled Syria rather than a grown man $(11,238 ; \text { LCL 4: } 97)^{10}$.

In his description of Demetrius' request to leave the Roman capital, Polybius in Histories 31,12 notices several important details. More than the oratorical skills of the young man, Polybius emphasizes Demetrius' attempt to eliminate potential doubts and suspicions about the true intentions of the future fugitive ${ }^{11}$ :

(...) he appeared before the senate and addressing that house begged and entreated to be sent home to assume the crown, to which he said he had a better claim than the children of Antiochus. When he had spoken at considerable length in this sense and especially appealed to his hearers by saying that Rome was his fatherland and his nurse, that the sons of the senators were all like brothers to him and the senators themselves like fathers, since he had come to Rome when quite an infant and was now twenty-three years of age, they were all personally affected, but their public decision was to keep Demetrius in Rome and help to establish on the throne the surviving child of Antiochus IV. The senate acted thus, in my opinion, because they were suspicious of a king in the prime of life like Demetrius and thought that the youth and incapacity of the boy who had succeeded to the throne would serve their purpose better $(31,2,4-7 \text {; LCL } 161: 183.185)^{12}$.

It is noteworthy that the senate used Antiochus $\mathrm{V}$ for its own purposes to permanently weaken the eastern empire. This strategy enabled Rome to realize the Treaty of Apamea in a favorable manner without the need of resorting to violence. After the assassination of the Roman proconsul Gaius Octavius, who had worked in Syria with the mission of destroying the Seleucid fleet and battle elephants, Demetrius went to the Senate again to request that he should be released from captivity. This time he did not back his demand with the death of Antiochus IV during whose rule Demetrius was a captive and who had died in an eastern

${ }_{10}$ Appian, Roman History 11: The Syrian Book, Vol. 3, trans. B. McGing, Loeb Classical Library (=LCL) 4, Cambridge (MA) 2019, p. 97.

${ }^{11}$ These suspicions turned out to be true later on when Demetrius had ascended the throne in Antioch and begun conducting the foreign policy of removing from power such allies of the republic as Ariarathes V of Cappadocia, P. J. Burton, Friendship and Empire: Roman Diplomacy and Imperialism in the Middle Republic (353-146 BC), Cambridge 2011, pp. 219-220.

${ }_{12}$ Polybius, The Histories. Books 28-39. Unattributed Fragments, Vol. 6, trans. W. R. Patton, rev. W. L. Walbank, C. Habicht, The Loeb Classical Library 161, Cambridge (MA) 2012, pp. 183, 185. 
military expedition, but he raised the argument that he had his own personal right to the throne. It should come as no surprise that this request was also rejected. This attitude stemmed from the basic principle of success in politics whereby the interlocutor should never be trusted and should be suspected of actions that may damage the welfare of one's own country. The right to the crown meant gaining support from the lieges particularly when the governing authority was unpopular, as was the case with Lysias' regency ${ }^{13}$. Thus, it becomes clear that the decision to keep the young Demetrius captive was made on a political basis - the desire to fully control the state of affairs in Western Asia where the republic wanted to exert considerable influence was clearly at play here. Polybius recounts it as follows:

(...) Demetrius again appeared before the senate and begged the house to release him at least from his obligation as hostage, as they had decided to secure the throne to Antiochus. After he had spoken at some length in this sense, the senate adhered to its original resolve, as was only to be expected. For on the former occasion it was not because Demetrius was not right in what he said that they had decided to keep the young king on the throne, but because it suited their own interest. And as the conditions remained the same, it was to be expected that the decision of the senate should be based on the same policy $\left(31,11,9-12\right.$; LCL 161: 201) ${ }^{14}$.

Both Marcus Junianus Justinus (Epitome 34,3) and Appian mention that the senators rejected Antiochus' request $(11,47)$. Historians unanimously conclude that the politics of Rome was based on the double-dealing treatment of their interlocutor. This two-facedness was manifested particularly in the assassination of Gaius Octavius. After the stabilization of Demetrius' rule in the Seleucid monarchy, the king sent a special delegation with gifts of serfdom and with the murderer of the Roman pronconsul - Leptinus ${ }^{15}$. The Senate accepted the gifts but did not want to receive the assassin. It did not want to temporarily interfere in this issue so that it might intervene in the monarch's affairs in the future through the potential indictment against the Seleucid king. Appian evaluates this policy in such a way ${ }^{16}$. Researchers note that the assassination of the proconsul could have been a good pretext for the declaration of war, as this scenario had happened multiple times in the past. However, future political factors triggered a change of Rome's

13 Lysias was the guardian of the juvenile Antiochus V.

14 Polybius, op. cit., p. 201.

15 Demetrius' decision to send commissioners was perhaps a political move aimed at preventing the senate from intervening into the Seleucid affairs on the pretext of seeking justice for murder, M. Taylor, Antiochus the Great, Barnsley 2013, p. 155.

16 C. B. Champion, Cultural Politics in Polybius's Histories, Berkeley-Los Angeles-London 2004, p. 161. 
attitude toward the Seleucid empire. Regardless of the moral evaluation of such politics, it was far-sighted from the point of view of the republic ${ }^{17}$.

As a result of two unsuccessful attempts to gain approval of the Senate, Demetrius fled from Rome in secret in the company of not too many allied friends and advisers. Marcus adds that the escape took place through the port of Ostia at the mouth of Tiber to the Mediterranean. Diodorus, who was the guardian of the future king and one of his closer advisers who had laid out a few important arguments, convinced Demetrius to escape from captivity. While closely watching the state of affairs in the Seleucid empire, Diodorus pointed to the general political confusion caused by the death of Antiochus IV and the mentioned assassination of the Roman proconsul. Thus, the people became averted toward Lysias, i.e. the guardian of Antichus V, who was a natural rival in the quest for the crown. Since there was a common conviction that supporters of the ruler had prepared the assassination attempt on the life of the Roman proconsul, the ruler would naturally have fewer supporters. The senate was also expected to use the death of one of its messengers in order to meddle into the internal affairs of Demetrius' kingdom in some way or another. All of this led to the decision that the throne should be assumed by Demetrius. Thus, there was a brilliant opportunity to arrive in the country and take over the authority. Among the participants of this secret plan were Diodorus, the historian Polybius, Menyllos, Appolonius, Meleager, Menestheus, Nicanor and some other dozens of people known from the detailed account of Polybius who also described the circumstances created to possibly mislead too inquisitive people $(31,20-22)$. The relatively significant independence of Demetrius is confirmed by the fact that no one in the Senate suspected anything on a few consecutive days; they erroneously thought that everyone had gone on a hunting trip ${ }^{18}$. The fact that Demetrius had managed to escape was noted also by Flavius Josephus in his Antiquities of the Jews, "About the same time Demetrius, the son of Seleucus, escapes from Rome and occupying Tripolis in Syria, placed the diadem on his own head $(12,10,1 \S 389$; LCL 365: 203)" 19 .

${ }^{17}$ This policy should be considered a typical example of utilitarianism, as pointed out by A. M. Eckstein, Moral Vision in the Histories of Polybius, Berkeley-Los Angeles-London 1995, p. 105.

${ }^{18}$ It could be suspected that the more liberal minority of the senators influenced Rome's decision to give up their chase after the fugitive. This can be concluded on the basis of the fact that Polybius' account is very detailed and that there is a kind of obvious pride related to being Demetrius' personal adviser in his decision to escape, E. Badian, Foreign Clientelae (264-70 BC), Oxford-New York 2000, p. 108.

19 Josephus, Jewish Antiquities, Vol. 5: Books 12-13, trans. R. Marcus, Loeb Classical Library 365, Cambridge (MA) 1943, p. 213; too The New Complete Works of Josephus, trans. W. Whiston, Grand Rapids 1999, p. 413. 
The addition of Tripolis in the above account suggests the possibility that Flavius Josephus used the text of 1 Macc and some other chronicles as his sources. Nevertheless, it is generally known that the most important source of information for him was the First Book of Maccabees. The evidence for this is exactly the same arrangement of the material in 1 Mch and Joseph's account, despite the lack of several details from the Jewish historian: the landing of Demetrius in a seaside city - gaining power in the empire - confrontation with Antiochus V and Lysias their immediate death by order of the new king - renegades' efforts Jews headed by Alcimus (1 Mch 7:1-5 and Ant. 12.10,1 § 389-391).

\section{Tripolis}

According to 2 Macc 14:1, in November of $162 \mathrm{BC}^{20}$, Demetrius gradually acquired power and support of the army as a legitimate member of the royal family standing above the regency of Lysias, who was the guardian of the juvenile Antiochus V.

The city in which Demetrius was supposed to arrive was the port city of Tripolis located on the Syrian coast (the Northern Lebanon today). This fact has been historically confirmed and the city was currently under the Seleucid control. It was an important center of economic life with the right to strike its own coins introduced already before Apamea, as confirmed by Antiochus IV ${ }^{21}$.

Why did the young successor to the throne choose this city? It is difficult to establish, although it is known that the city had served as the center of three seaside cities, i.e. Tyre, Sidon and Arwad (Arados) since the half of the third century BC. The city existed already in the Persian epoch ${ }^{22}$. Each of the cities had its own district in Tripolis which had become the seat of government of this confederation $^{23}$. Diodorus Siculus writes about it in his Bibliotheca Historica:

In Phoenicia there is an important city called Tripolis, whose name is appropriate to its nature, for there are in it three cities, at a distance of a stade from

20 J. A. Goldstein, I Maccabees. A New Translation with Introduction and Commentary, The Anchor Bible 41, Garden City 1976, p. 329; B. Bar-Kochva, Judas Maccabaeus: The Jewish Struggle Against the Seleucids, Cambridge 1989, p. 544.

${ }^{21}$ O. Mørkholm, Early Hellenistic Coinage. From the accession of Alexander to the peace of Apamea (336-188 B.C.), Cambridge 2001, p. 110; O. Picard, F. de Callataÿ, F. Duyrat, G. Gorre, D. Prévot, Royaumes et cités hellénistiques: de 323 à 55 av. J.-C., Lassay-les-Châteaux 2003, p. 92.

${ }_{22}^{2}$ Dictionnaire de la civilisation phénicienne et punique, ed. E. Lipiński, Turnhout 1992, p. 471.

${ }^{23}$ International Dictionary of Historic Places, Vol. 4: Middle East and Africa, ed. T. Ring, N. Watson, P. Schellinger, Chicago 1996, p. 704. 
one another, and the names by which these are called are the city of the Aradians, of the Sidonians, and of the Tyrians. This city enjoys the highest repute amongst the cities of Phoenicia, for there, as it happens, the Phoenicians held their common council and deliberated on matters of supreme importance $(16,41$; LCL 389: 351) ${ }^{24}$.

The location of Tripolis and its convenient geographical conditions were the reason why it quickly became a garrison city, where significant military forces were stationed ${ }^{25}$, and where shipyards operated ${ }^{26}$. After some time, i.e. at the beginning of the Hellenistic epoch, Tripolis probably became autonomic and independent, as suggested by several important notes ${ }^{27}$. For these reasons, Tripolis may have been a convenient point of departure for Demetrius in his quest for the crown of the empire in Antioch. Ancient historians agree that Demetrius met with a friendly and enthusiastic reception ${ }^{28}$.

Such a reaction to the arrival of the new candidate to the crown means that the central government ruled ineffectively over the cities. These cities were unsatisfied with the current system of power and were trying to gain a privileged spot during a possible change of power. It comes as no surprise that Antiochus IV Epiphanes was the last ruler who was capable of maintaining relative integrity of the entire large empire regardless of his incapability to fight back the Maccabean revolt in such an insignificant province territory-wise as Judea. However, it is also known that Antiochus IV, in his quest for the unity of his monarchy, gave a whole array of cities located on the Phoenician coast the privilege to strike their own coins - among those cities as already mentioned was Tripolis itself. This privilege actually meant that the cities were granted significant areas of autonomy inside the empire. As central authority became weaker with time, the

${ }^{24}$ Diodorus Siculus, Library of History, Vol. 7: Books 15.20-16.65, trans. C. L. Sherman, Loeb Classical Library 389, Cambridge (MA) 1952, p. 351.

${ }^{25}$ This is similar to Tyre and Sidon. The troops were stationed mostly in the barracks where arsenals of different weaponry were stocked, P. Briant, Histoire de l'Empire perse, de Cyrus à Alexandre, Paris 1996, pp. 817-818.

${ }^{26}$ Mentioned along with Byblos in Diodorus' Bibliotheca Historica 19, 58,4.

${ }^{27}$ Since the city alone is not the main subject of the present paper, refer to F. Duyrata, Arados hellénistique. Étude historique et monétaire, Beyrouth 2005, p. 219 for more details. It is important to note, however, that the role of this city in the Roman times was continuously rising to an extent where it had become a political and economic center thanks to the modernization of roads for hearses that delivered material goods. Tripolis began to compete with the seaside city of Arwad (Arados) that was mightier and was located further north, J.-P. Rey-Coquais, Arados et sa pérée aux époques grecque, romaine et byzantine, Paris 1974, p. 80. Rich archaeological material can be found in H. Salamé-Sarkis, Chronique archéologique du Liban-Nord. I. Fouilles d'El-Mina-Tripolis, "Bulletin du Musée de Beyrouth" 24(1971), pp. 91-102.

${ }^{28}$ This is mentioned by Appian (Roman History 11,47), Marcus Junianus Justinus (Epitome 34,3) and Flavius (Antiquities of the Jews 12,10,1 § 389). 
cities were becoming significantly more independent from the capital although their status remained limited. This fact is worthy of emphasizing because the city was one of the few that had existed for many centuries before the Seleucid reign and had their own rights and ways of functioning. These cities were capable of defending their ways of functioning even in a militarily way so as to counteract possible dependence from the central authorities.

\section{Political Consequences of Demetrius' Escape}

According to Polybius, the Roman Senate began to act after learning about the escape of the young king; it knew about it on the fourth day after the escape of the captive and his friends who had reached a bridgehead in their own country by sea. Having given up on the chase, the republic contented itself with sending three commissioners who additionally received a mission in Greece to later go to Asia and closely watch the subsequent course of events. Polybius states:

(...) on the fifth day, when Demetrius had already passed the Straits of Messina, a special meeting of the senate was held on the subject. Any idea of pursuit was abandoned because on the one hand they supposed that he was well advanced on his voyage, as the wind was favourable, and on the other hand they saw that they could not prevent him even if they wished. After a few days they appointed three commissioners, Tiberius Gracchus, Lucius Lentulus, and Servilius Glaucia to examine first of all into the state of Greece, and then, crossing to Asia, to await the result of Demetrius's action, and to inquire into the sentiments of the other kings, and decide the differences between the latter and the Galatians. The reason why they appointed Tiberius Gracchus was that he had personal knowledge of all these subjects $\left(31,15.7-11\right.$; LCL 161: 213) ${ }^{29}$.

It appears that the mission targeted at Demetrius was the main reason behind sending the commissioners who were additionally supposed to take care of other important political events on the east. Having sent the commissioners to Asia, the Senate also wanted to control the situation and demand that the Peace of Apamea be respected. This was supposed to gradually lead to a complete disarmament of the Seleucid monarchy so that it became defenseless against the mighty repub$\operatorname{lic}^{30}$. By wanting to permanently intervene in the Seleucid monarchy when the time was right, the senators stood in the way of Demetrius' future plans with regards to both internal and worldwide politics. For the Senate was engaged in

\footnotetext{
${ }^{29}$ Polybius, op. cit., p. 213.

${ }^{30}$ B. Bar-Kochva, op. cit., p. 548.
} 
the rebellion against the young king incited by the main satraps of the empire, i.e. Timarchus, the satrap of Babylon, his brother Heracleides, the satrap of Media and Ptolemy, the satrap of Commagene, whom ultimately the Seleucid king managed to defeat ${ }^{31}$. Another move was to support Judas Maccabeus as a reaction to Demetrius' self-reliance in the state that he had already ruled over ${ }^{32}$.

\section{Theological Plane of the Analyzed Passage}

In this section, the text of the analyzed verses of chapter 7 of the First Book of Maccabees will be repeated for convenience sake ${ }^{33}$. The hagiographer fits in with the general knowledge of the historical origin of the main character, mentioning that he was "the son of Seleucus" and that he was in Rome, though he omitted the detail that he was a hostage there. He also does not provide details on the reasons for imprisonment of Demetrius in the capital of the Republic, the conditions of his stay, escape plans and assistants cooperating in this project. The slight discrepancies among ancient historians as to the motivation of his desire to regain the throne of his deceased uncle, Antiochus IV, do not significantly influence Demetrius' decision to secretly leave Rome. The age of the main character is missing as well as Demetrius' reasons which he presented before the Senate to obtain permission to leave the city. We also have to accept the lack of a mention that the senate forbade Demetrius from leaving Rome, as well as the justification for this prohibition. The author does not write about the possible political consequences of the escape from Rome of a young candidate for the Seleucid crown and the further actions of the senate. Most likely, these historical additions were not necessary for our author in his narrative or did not fit theological goal, which was the primary purpose of writing the entire book. There are many indications that he knew the exact spot where Demetrius' troops had arrived on the coast of their country, which happened in the late fall of $162 \mathrm{BC}$. The main cities that lay on the Phoenician coast were at the time Sidon, Tyre, Ptolemais, Dora, Joppa, Jamnia, Azotus, Ashkelon, Gaza and Ashdod. Their geographic location clearly indicates that only Tripolis could count as a possible landing site for Demetrius and his troops, as they were closest to Antioch, the then capital of the Seleucid Empire. They were not in any way endan-

${ }^{31}$ R. Doran, The first book of Maccabees, in: The New Interpreter's Bible, ed. L. E. Keck, D. L. Petersen, Vol. 4, Nashville 1996, p. 93; E. Wipszycka, B. Bravo, Historia starożytnych Greków, t. 3: Okres hellenistyczny, Warszawa 2010, p. 405; A. Ziółkowski, op. cit., p. 615.

32 D. Gera, Judaea and Mediterranean Politics: 219 to 161 B.C.E., Leiden-New York-Köln 1998, pp. 314-315.

33 This part of the article is an extension of the remarks contained in the second volume of my commentary to the book and the comparison of historical sources with the text of the book, absent in this commentary, J. Nawrot, Pierwsza Ksiegga Machabejska..., op. cit., pp. 102-107. 
gered by the intervention of foreign armies and, belonging to the monarchy, were a safe place for visitors from Rome. The hagiographer should know this very well.

\section{Escape of Demetrius from Rome}

v. 1: "In the one hundred fifty-first year Demetrius, son of Seleucus, set out from Rome, sailed with a few men to a city by the sea, and there began to reign".

It is possible that our author did not name the city deliberately by writing merely about polin parathalassian, that is a "seaside city". The noun parathalassia can be found in the prophetic text of Jer 29:6-7 [LXX] which foreshadows God's sword against parathalassious, "the seashores", that is the state of Philistines. This sword will come from new invaders that will destroy the mentioned land. It is known that Jeremiah's prophecy came entirely true in $604 \mathrm{BC}$ when Nebuchadnezzar, after winning the Battle of Carchemish, invaded the Canaan land and destroyed the above Philistinian cities ${ }^{34}$. These cities had always been hostile to Israel by taking advantage of its weaknesses and by fighting with God's people. In the present context, one should note that the God of Israel is using a Gentile king to avenge other Gentiles for their uncompromising attitude toward His people regardless of how innocent they were with regards to their own situation. The inspired author likens Demetrius I's homecoming to another campaign of the Babylonian king; just as he slew particular rulers and destroyed their lands, Demetrius is now going to kill the current ruler and his regent, which again is going to be a punishment for their battle with members of the chosen people ${ }^{35}$. This way Demetrius will become a convenient means through which Jeremiah's prophecy about Antiochus and Lysias should be fulfilled - this is confirmed by the theology conveyed in verse 6:63.

Yet, Ezek 25:9 appears to be closer to the subject matter in question - it has the same construction of poleos parathalassias in the context of the proclamation against Moab which foreshadows a punishment from the God of Israel (vv. 8-11). The prophet first reveals the guilt of the Moabites who liken the House of Judah to Gentile nations (v. 8). This comparison downright negates the Judeans' identity as God's chosen people privileged to have their own religion and to live in harmony with His commandments regardless of the fact that they had already

${ }^{34}$ J. A. Thompson, The Book of Jeremiah, New International Commentary on the Old Testament, Grand Rapids 1980, p. 698.

35 This statement is not at variance with an additional conclusion that the former ruler and his minister deserved to be punished for resistance against the new candidate to the crown, F. B. Huey Jr., Jeremiah, Lamentations. An Exegetical and Theological Exposition of Holy Scripture, New International Version - New American Commentary 16, Nashville 1993, p. 386. 
rejected this way of life. The chosen people have already been punished multiple times in the past. But this punishment should not, however, become the reason for the Gentiles' ridicule and scorn for the chosen people by likening them to the Gentiles especially with regards to practiced idolatry. The addition of the proclamation against the Ammonites in Ezekiel's prophecy points explicitly to the origin of both peoples, that is their ancestors' - i.e. Moab's and Ammon's immoral conception from an incestuous relationship of Lot's daughters with their father (Gen 19:30-38) ${ }^{36}$. Under no condition should God's people be likened to other peoples of such immoral provenance. The use of poleōs parathalassias in the Septuagint is a Greek counterpart of the cities located on the eastern coast of the Dead Sea which were fortified settlements in the Moabite land destined for destruction (v. 9) ${ }^{37}$.

It is easy to associate the meaning of the prophetic accusation against Moab with the direction of Lysias and Antiochus V's actions who want the Jews to be merely one of the many peoples in the whole empire with no distinctive features whatsoever. This attitude to the chosen people will bring them such consequences as being eliminated from the pages of history similar to the Moabites who were annihilated by Nebuchadnezzar in the same campaign of $604 \mathrm{BC}$. It is noteworthy that the seaside cities will be destroyed according to both prophetic proclamations whereas one of them is going to be the starting point for the invasion of the new ruler on the rest of his country, as 1 Macc 7:1 relates. The different points of view of the biblical authors can be explained by the fact that poleis parathalassias are a faithful and integral part of their own kingdoms in both proclamations while Tripolis, which is denoted by polis parathalassias, is actually separated from the rest of the empire still governed by Antiochus V. Thus Tripolis will be temporarily favored as a bridgehead for invasion by the new claimant to the throne. With time, though, Tripolis will also experience the burden of his reign. The hagiographer uses both proclamations to likely foreshadow a much later fate of the city ${ }^{38}$.

There is, however, a surprisingly considerable difference in the estimated number of Demetrius I's companions during his arrival on the western coast of his homeland. While the author of 2 Macc 14:1 mentions plèthous ischyrou, i.e. "a considerable number of troops", the hagiographer of the First Book, quite to the contrary, speaks about andres oligoi, i.e. "few men". His recount corresponds

${ }^{36}$ L. E. Cooper Sr., Ezekiel. An Exegetical and Theological Exposition of Holy Scripture, New International Version - New American Commentary 17, Nashville 1994, p. 247.

${ }^{37}$ L. C. Allen, Ezekiel 20-48, Word Biblical Commentary 29, Dallas 1990, p. 67.

${ }^{38}$ In a paradoxical manner, it was not until 9.7.551 AD that Tripolis had experienced an earthquake and tsunami that flooded the city and killed its inhabitants, Ancient Earthquakes, ed. M. Sintubin et al., Special Paper 471, The Geological Society of America, Boulder 2010, pp. 99-106. In the previous epochs, particularly after the incorporation of the city into the Roman empire, Tripolis started to develop significantly due to its strategic location. 
with Polybius' writing when he mentions the circumstances and the names of only a dozen friends who assisted Demetrius in his escape. It is truly difficult to combine these two versions unless the text of the Second Book of Maccabees which is not written as a chronological continuation of the First Book, but should be rather understood as a parallel version of the First Book - should be read a little different by combining "a strong army and a fleet" (belonging to v. 1) with the text of v. 2 as its beginning. This way it is easy to comprehend the sense of this account which fails to mention the number of Demetrius co-fugitives escaping from Rome and which draws attention to the troops that gathered later and the attack on the empire's capital. The sequence of events seems to be understood in the same way by Flavius, who separates the news of Demetrius' arrival in Tripolis from the possible and subsequent gathering of a sufficient number of troops which invade Antioch and take the control over the city. The author of the First Book notes, in turn, that few men arrived in the city, which is totally in line with the account of Polybius $(31,20-22)$. However, there is no mention of how the claimant to the crown was able to make a stop and recruit troops for combat immediately after the arrival to his own country. This draft would have been particularly difficult to carry out since new ships and weaponry would have been required and that would have surely lasted several months. This hypothesis should, therefore, be invalidated.

The above expression andres oligoi in 1 Macc 7:1 might, in turn, relate to 2 Chron 24:24 where a limited number of Gentile troops defeated mightier Judean forces. This defeat happened out of God's will; He let the Judeans fall in the hands of the Arameans as a punishment for committed idolatry ${ }^{39}$. Likewise, a small number of Demetrius' companions will defeat the greater army of Lysias, and that will be God's punishment for the chosen people's misdeeds in Judea. But the reference to the above text might also signify a different and much more serious forecast of future actions taken by Demetrius against the Jews, should they reject the only right motivation behind the insurrection, that is the defense of the Law and the Covenant as laid out by Mattathias. It is already known that Judas began to almost imperceptibly deviate from the path of fidelity after a whole series of successful military operations whose coping stone was the rescue of some fellow Jews in Gilead (1 Macc 5). He did so by taking actions more out of his own initiative than through reliance on the Lord. The first sign of failure was

${ }^{39}$ The passage of Josh 7:3-5 recounts a very similar situation where the inhabitants of $\mathrm{Ai}$ defeated the much greater Israeli army whose leaders ignored the strength of the Gentile troops and disobeyed the law of herem which forbids stealing anything from the enemy thereby committing a serious offense. The defeat conceded in the city confirmed by the words of God Himself (vv. 11-12) is a meaningful result of this offense, D. M. Howard Jr., Joshua. An Exegetical and Theological Exposition of Holy Scripture, New International Version - New American Commentary 5, Nashville 1998, pp. 189-195. 
the inability to conquer the Acra in Jerusalem (6:32) and the military success in some operations of Antiochus V and Lysias' troops in Judea. Luckily, it was sheer providence that they did not suppress the whole insurrection (6:47-63).

The expression eksêlthen... ebasileusen, "he set out ...he began to reign", although completely consistent with the historical message, resembles much more a similar expression in the description of Alexander the Great (1:1) and Antiochus IV (1:10) where the actions of both kings are presented as a beginning for a new epoch of decay in the history of humanity - the climax point of this era is going to be the persecution of the Jews. Cultural otherness of the current invader is evaluated as a threat to the Jewish faith, culture and tradition. This invasion is realized through attempts to impose or take over these cultural elements by the local Establishment, which will shortly be confirmed by a quick visit paid to Demetrius by a whole bunch of apostates from the Law and national traditions $(7: 5)^{40}$. Despite the obvious continuity of the Hellenistic age, Demetrius' reign begins a new stage in the empire's history. Similar to Alexander, who originally turned the world upside down, and Antiochus, who later subverted the relative order particularly in Judah, Demetrius will also mark his name on the cards of the chosen people's history. All of this explicitly suggests that Demetrius' reign should, at the end of the day, also be evaluated negatively by the reader. This evaluation confirms the above thesis that the insurrectionists should completely abstain from supporting Demetrius after learning about his ascent to the Seleucid throne ${ }^{41}$.

This conclusion can also be drawn when looking at another juxtaposition of eksēlthen ... anebe e, "He set out... sailed" or "left... ascended". The oracle of Jer 4:7 foreshadows a destroyer's departure (anebe $)$ ) and abandonment (eksēlthen) of his own place in the north; he will turn the Promised Land into a desert, ruin its cities and drive out its inhabitants. This is a dramatic harbinger of punishment which God is preparing for His disobedient people who do not want to convert and realize the call to circumcise their hearts (v. 4), which means submission to the terms of the covenant. It should be stressed that this call relates to the inhabitants of Judea and Jerusalem, who are the main addressees of this message. They cannot sleep peacefully even when v. 7 the prophet mentions the destruction of the Gentile nations. If God does this with the Gentiles, He will do this even more so with the unfaithful members of the chosen people who disobey the terms of

${ }^{40}$ U. Rappaport, The Hellenistic World as Seen by the Book of Daniel, in: RASHI 1040-1990: Hommage à Ephraïm E. Urbach. IV Congrès européen des Études juives, ed. G. Sed-Rajna, Cerf, Paris 1993, pp. 71-79.

${ }^{41}$ Happily to the insurrections, the new king shortly showed his anti-Judean attitude by allying himself with the Jewish renegades whom he gave power and by sending his troops to combat in Judea (7:5-10). 
the covenant $\mathrm{t}^{42}$. The battle which emerges on the horizon of the Maccabean revolt, i.e. another war declared by Demetrius, can be seen in similar terms. Demetrius' arrival must be interpreted as a sign of upcoming God's wrath. Before Demetrius begins combat with the insurrectionists and all the people, he will first have to kill his adversaries, which the author will shortly mention. Similar to when Jeremiah called for penance, lamentation and wail for previous infidelity (v. 8), the leaders of the insurrection should deeply reflect on whether they are going down the right track as long as there is still time for conversion. Otherwise, they will lack courage and wisdom when confronted with the mighty threat posed by their enemy (v. 9) $)^{43}$. In the author's of 1 Macc point of view, Judas' departure from the revolt's original direction should definitively end. The leader should stop acting on his own and should return to authentic fidelity by giving his own initiative to God himself instead of trusting his own political and military skills.

\section{The Death of Antiochus V Eupator (7:2-4)}

v. 2: "As he was entering the royal palace of his ancestors, the army seized Antiochus and Lysias to bring them to him".

The author changes the place of action from Tripolis to Antioch, the empire's capital, which is located over $260 \mathrm{kms}$ from the port city. He does not enrich the description with detailed events which could have happened in the meantime, but he instead emphasizes the very moment of arrival or - in a broader sense - the takeover of his ancestor's cities. It is likely that the inspired author thus wants to stress that neither Anitochus IV nor his son had the right to the crown as an inheritance from Seleucus IV. It was Demetrius I who - regardless of his notoriety - retained this right regardless of being unable to use it because of Rome's policies.

The expression oikos basileias, "the house of kingdom" does not mean "a palace of power" 44 in a strict sense, but it means - in general terms - the country's capital and the headquarters of the ruling monarch ${ }^{45}$. However, in light of $1 \mathrm{Macc}$ $2: 19$, the meaning of the present expression might be even extended to the entire monarchy where the exact construction oikos tēs basileias tou basileōs is likely

${ }^{42}$ L. C. Allen, Jeremiah. A Commentary, Old Testament Library, Louisville-London 2008, p. 65 .

${ }^{43}$ F. B. Huey Jr., op. cit., p. 81.

${ }^{44}$ This sense is conveyed, for instance, in verses Amos 7:13; 2 Chron 1:18; 2:11.

${ }^{45}$ Dan 4:30 and Hebr. bet-melek, 1 Kgs 15:18; 16:18; 2 Kgs 11:20; 15:25; Jer 19:13; 21:11; $22: 1.6 ; 27: 18.21 ; 32: 2 ; 33: 4 ; 38: 22$. 
a Hebraism understood as a territorial range or the domain of the ruler's reign ${ }^{46}$. It is rather clear that the king has an opportunity to rule over his whole monarchy after he assumes the throne although it was not that clear in times of Demetrius when the political situation in his country was overly complicated. But coming to the throne gave the ruler the right to defend his own holdings against any other usurpers. According to 2 Sam 16:3, dynastic inheritance might be here at work such a meaning would explain the sense of the hagiographer's account ${ }^{47}$.

Another expression - synelabon hai dynameis, "the troops captured" might be perhaps interpreted in the light of Jer 45:3 [LXX] which mentions the deliverance of Jerusalem in the hands of Nebuchadnezzar II's troops ${ }^{48}$. One should remember that the words of this oracle are uttered by the prophet on behalf of God. The operations of the invading troops derive thus from God's will and are His punishment for the infidelity and resistance of the inhabitants of the capital toward God's continuous calls to conversion and obedience to the Covenant and the Law (Jer 44:2 [LXX]). Because this judgment comes from the Lord, it means that it is irrevocable ${ }^{49}$ and that the capture of both the juvenile Antiochus $\mathrm{V}$ and Lysias might be seen as determined by God. This seizure introduces an actual takeover of the whole capital similar to what the Babylonian king once did with Jerusalem.

Another combination of the verbs syllambano and ago, "I bring", is also present in the double account of $2 \mathrm{Kgs}$ 25:6 and Jer 52:9 [LXX] which recount the seizure of king Zedekiah and his being brought to Nebuchadnezzar who sentenced the king to excruciating mutilation and banishment to Babylon ${ }^{50}$. It is important to mention that the seizure of the last ruler of the independent Judea was carried out far away from the place where he had camped that was located in the

${ }^{46}$ Like in Ezr 7:23; Dan 11:9; 1 Es 8:21, J. Nawrot, Kryzys religijny w Judei..., op. cit., pp. 429-430.

${ }^{47}$ More so because a similar context reveals the possibility of ruining the empire's integrity as was the case during the battle between David and the remnants of Saul's dynasty, J. Vermeylen, La maison de Saül et la maison de David, in: Figures de David à travers la Bible. XVII congrès de l'ACFÉtudes Bibliques: Lille, 1-5 septembre 1997, Association Catholique Française pour l'Étude de la Bible, Lectio Divina 177, Paris 1999, p. 71.

${ }^{48}$ Research on the Book of Jeremiah has revealed a literary topos whereby an army has come a long distance, most often by sea. This characteristic suggests that it was a foreign army that has taken up arms against those countries which it has never dealt with before. This feature, in turn, implies that the army must have acted exclusively under the imperial command of its ruler, D. Bourguet, Des métaphores de Jérémie, Études Bibliques 9, Paris 1987, pp. 191-194.

49 J. A. Thompson, op. cit., p. 637.

${ }_{50}$ The very punishment has already been described by Prophet Ezekiel who foreshadows, on behalf of God, the ultimate fate of Zedekiah blinded by the winning army. Ultimately, the God of Israel controls everything - He is shown to be hunting for His victims using people and situations even in such a drastic way (12:11-14), D. I. Block, The Book of Ezekiel. Chapters 1-24, New International Commentary on the Old Testament, Grand Rapids-Cambridge 1997, p. 377. 
strategic city of Riblah. The arrest of the juvenile Seleucid king and his minister was made, in a similar way, far away from the capital of the Seleucid monarchy. Regardless of the fact that the above quotations and the hagiographer's text share some similarities place-wise, not theology-wise ${ }^{51}$, God is always the One who decides about the fate of all the people on Earth by using His chosen individuals. Therefore, every common or mighty man must ultimately pay for his misdeeds.

The note on Lysias, which is unique among ancient historians and Lysias' capture by the troops of Demetrius along with the young Antiochus V, speaks strongly in favor of the fact that Flavius drew his news from the text of 1 Macc.

v. 3: "But when this act became known to him, he said, «Do not let me see their faces!»".

Having written that the act became known to Demetrius, the author seems to suggest that the arrest of Antiochus $\mathrm{V}$ and Lysias was an independent activity of his generals. This conclusion does not, however, in any way exclude the possibility of Demetrius' having issued an arrest warrant against his enemies. Now he might have learned about the time, place and possible circumstances of their capture $^{52}$. These revelations are going to influence his attitude and decisions such as those regarding capital punishment which prohibited the convict to look at the monarch's face. The custom of covering one's face was widely known as a way of showing mourning ${ }^{53}$ or shame $^{54}$ in Greco-Roman culture. The author of 1 Macc is very well versed in the customs of his time at royal courts. But this custom was also used to turn the condemned man away from the ruler's kindness and his

${ }^{51}$ This is not about a member of the chosen people, but a Gentile ruler who fights against the Jews. Meanwhile, this difference does not matter in God's eyes who sees an evil act regardless of who commits the sin against their neighbor. Such a misdeed is evaluated negatively and deserves a righteous punishment.

52 The expression ginōsko to pragma, "I learn about an issue or a thing" is well documented in Greek classical literature where the phrase accentuates the knowledge which influences the behavior of both its sender and recipient. (inter alia Andocides, On The Mysteries 134; On His Return 10; Against Alicibiades 1; Antiphon, On the Murder of Herodes 8; Demosthenes, Against Timocrates 5; 206; Against Onetor 18; Against Stephanus 17; Diodorus, Bibliotheca Historica 14, 97,4; 15, 9,3; Polybius, Histories 4, 111,1; Isaeus, Pyrrhus 72; Isocrates, Panathenaicus 226; Against Lochites 18). But the expression in question is also present in another biblical quotation, i.e. Gen 21:25-26, where it conveys a different sense; when Abraham and Abimelech were making a pact, the former complained to Abimelech about a well of water that Abimelech's servants had seized (v. 25) to which Abimelech replied that he had not known about this (ouk egnōn... to prāgma) and therefore he took no action.

${ }_{53}$ Aristophanes, The Frogs 907.

${ }^{54}$ Aeschines, Against Timarchus 46; Plutarch, Lycurgus 11,2. 
execution, as described in Esth $7: 8^{55}$, although the Septuagint suggests that even Haman's face was covered (dietrape to prosōpō) most likely due to shame or fear, which is conveyed through the verb diatrepō. Some Jewish commentators speak of Haman covering his face with his own hands in the hope of alleviating the king's anger ${ }^{56}$. In Est 6:12, Haman covered his own face in order to publicly reveal his anger and grief, although it is more likely that he did so out of humiliation $^{57}$. According to Job 9:24, God covers judges' faces probably to deprive his own people of righteous judgment and to leave them to the grace of tyrants ${ }^{58}$. Summing up, one may conclude that the prohibition against the revelation of convicts' faces issued by Demetrius was probably supposed to prevent the two condemned men from asking for pardon from capital punishment. However, the practice of covering their faces might also have served to show contempt for the convicts or to show them, in a symbolic way, that they had stopped to exist and had become nobodies ${ }^{59}$.

v. 4: "So the army killed them, and Demetrius took his seat on the throne of his kingdom".

The assassination of the inconvenient juvenile ruler and his guardian allowed for the purgation of the political situation in the monarchy and, paradoxically, for the stabilization around the one center of power, that is the new king. Whenever the author mentions that this stabilization was introduced by hai dynameis, "the troops", "the forces", he does not mention the general sense of the army which, in the meantime, must have changed sides to Demetrius. But the author mentions a sort of firing squad which executes the monarch's order. The expression apekteinan autous hai dynameis, "the armies killed them" might be particularly interesting in the light of 2 Chron 28:9-11, which is the only text that includes this very combination of words denoting, in the same way, the army's operations toward executing a massacre of the enemy. The above text mentions a fratricidal battle between the Israelites and the Judeans that turned victorious to the Israelites who had killed their adversaries (apekteinate en autois) because of God's wrath against them. At that time, Prophet Oded began to warn the victors not to enslave their defeated compatriots, which the winners were capable of doing,

${ }_{55}$ This is shown in the grammatical construction $\hat{u} p^{e} n e \hat{~ h a m m a n ~ h a ̄ p h u, ~ M . ~ B r e n e m a n, ~ E z r a-~}$ Nehemiah - Esther. An Exegetical and Theological Exposition of Holy Scripture, New International Version - New American Commentary 29, Nashville 1993, p. 350.

56 a.o. Księga Estery z komentarzem Malbima, Kraków 2004, p. 125.

${ }^{57}$ F. Bush, Ruth/Esther, Word Biblical Commentary 9, Dallas 1996, p. 420.

${ }_{58}$ D. J. A. Clines, Job 1-20, Word Biblical Commentary 17, Dallas 1989, p. 238.

${ }^{59}$ Such a fate was suffered by the Messianic Servant of Yahweh in accordance with the oracle of Isa 53:3. 
as the prophet had observed the enormous cruelty they inflicted on the losers (vv. 9-10a). These along with the earlier sins of the Israelites should remain with them as a powerful message that God will not tolerate the unrighteous deeds against the loser members of His people (v. 10b). If the victors do not let their enemies free, they will have to endure a punishment from God (v. 11). Perhaps the extract from 1 Macc should be understood in similar terms - that is as a warning directed to Demetrius who, having ordered that his rivals be killed, is now trying to control the Jews as a new Seleucid ruler. Because their death is obviously God's punishment for their former actions toward the Judeans, Demetrius - who is using similarly brutal methods - should not enter conflict with those whom God will always support as the sons of His people regardless of their sins.

The beginning of Demetrius' reign was denoted through the phrase ekathisen epi thronou, "he took his seat" ${ }^{60}$. The crowning happened in the context of a bloody debate with opponents of Demetrius' reign. The above expression undoubtedly has a theological sense, since none of the ancient historians uses it in describing the beginnings of Demetrius' reign. Josephus describes the coronation of the king with the phrase peritithēsin men heauto diadēma, "set the diadem on his own head" (Ant. 12,10,1 § 389). The other historians mention only in general terms the fact that Demetrius became the ruler of the empire.

Many other rulers of the ancient Israel and Judea had had a similar coronation in the past ${ }^{61}$. The closest biblical counterpart to Demetrius was Zimri, who had hatched a plot against the ruler of the Kingdom of Israel coming from the House of Baasha. Having murdered the king and having gotten rid of any pretenders to the crown both from his family and from among his friends who could question his usurpation in the future (1 Kgs 16:9-11), Zimri was seated on the throne. Obviously, the similarity between Demetrius and Zimri can only be seen in the context of authority takeover ${ }^{62}$, but the author reminds that this coup was carried out in accordance with an earlier harbinger uttered by the prophet on behalf of God. This way it is God Himself who stands behind these events, knows the future, and is capable of predicting it and its consequences. Subsequent to Zimri, there was also Jehu, who was anointed as King of Israel by Prophet Elisha and

${ }^{60}$ In numerous ancient texts, ascending and descending the throne (kathidzo epi thronon) denotes a takeover of power (Flavius, Antiquitqtes 7, 14,5,6,11; Diodorus, Bibliotheca Historica 17, 66,3; 116,2-3; Arrian of Nicomedia The Anabasis of Alexander 7, 24,1-2; Plutarch, Theseus and Romulus 5; Alexander 30, 7; On brotherly love 18; Dio Chrysostom, Prayers 13, 24; Claudius Aelianus, Varia Historia 7, 1; Philostratus the Athenian, Life of Apollonius of Tyana 2, 41) or judiciary (Herodotus, Histories 5, 25,2).

${ }^{61}$ e.g. Solomon (1 Kgs 2:5-9) and Jonah (2 Kgs 11:14-17.19).

${ }^{62}$ One should bear in mind that Zimri was not a legitimate successor to the throne unlike Demetrius, the text exegesis in S. J. De Vries, 1 Kings, Word Biblical Commentary 12, Waco 1985, p. 197. 
was expected to eliminate all the claimants to the crown from the House of Omri and avenge God's servants killed by Jezebel, the wife of Ahab (2 Kgs 9:6-10) ${ }^{63}$. Again, what becomes apparent is the issue of God's irreversible action, which is a punishment for all the evil that the dynasty had done to God's chosen people by dissuading them from their Lord. Finally, the similarity of power takeover can be observed in the series of events related to Athaliah, the daughter of Ahab and Jezebel. She maintained power in Judea for a short period of time after the death of her son Ahaziah. She had murdered all the members of the royal family who could oppose her takeover (2 Kgs 11:1-3). If one were to find a theological reference to this situation, one should consider it in terms of factual opposition; contrary to Demetrius, Athaliah was a usurper on the throne of Judea by coming to power only on the basis of being the wife of David's descendant. There is no other way she could have been able to carry out her deadly plan. All the above rulers received the crown at the expense of their predecessors' lives. Every one of them (along with the members of their families) would eventually be murdered by their successors as a result of God's righteousness. A similar death will also be reserved for the one who has now begun his reign on the Seleucid throne in Antioch.

\section{Conclusion}

To sum up, the biblical account of the First Book of Maccabees and the ancient historiography presented by various Greek and Roman authors across different times are mutually consistent. Like in the whole book, the inspired author was determined to place the presented events in a proper time-and-place structure. This effort was necessary for drawing an appropriate theological interpretation conveyed by the hagiographer through his work. God will not allow the authors of His Word to create artificial or false historical facts for the reader's sake, but He always works on the foundation of real events. While the Gentiles can also be part of these events, they are always somehow involved in the history of God's chosen people. This way the Lord is shown to have a real, complete and decisive influence on history, which, in one way or another, always shows His wisdom and omnipotence.

${ }^{63}$ M. A. Sweeney, I \& II Kings. A Commentary, Old Testament Library, Louisville-London 2007, p. 333. 


\section{Zdobycie tronu przez Demetriusza I Sotera (1 Mach 7,1-4). Interpretacja teologiczna wydarzenia historycznego}

\section{Streszczenie}

Prezentowana perykopa biblijna 1 Mch 7,1-4 opisuje wydarzenie, które miało miejsce daleko poza zasięgiem działań powstańców machabejskich. Jest jednak ściśle związana $\mathrm{z}$ historią narodu wybranego i w istotny sposób wpływa na ewolucję sytuacji polityczno-religijnej Żydów w tym okresie. Szczególnie warta analizy jest adekwatność prezentowanych faktów historycznych oraz teologiczne spojrzenie na nie, którym autor nadaje pierwszorzędne znaczenie. Temu właśnie poświęcony jest niniejszy artykuł zestawiający dane historyków starożytnych z relacją biblijną. W ten sposób historia narodów i królestw ukazana jest jako część wielkiego planu Bożego realizującego się nawet nieświadomie poprzez działanie uczestników toczących się wydarzeń. Taka prezentacja dotyczy bohaterów zarówno głównych, jak i drugoplanowych. Krótki fragment 1 Mch 7,1-4 pokazuje, jak hagiograf świadomie uwypukla pewne fakty, dobiera odpowiednią składnię i słownictwo, aby ukazać działanie Boga. Wprawdzie stoi On za zasłoną ludzkich działań, ale właśnie On decyduje ostatecznie o ich przebiegu.

\section{Słowa kluczowe}

egzegeza biblijna, Septuaginta, Pierwsza Księga Machabejska, Demetriusz I Soter, powstanie machabejskie

\section{Summary}

The presented biblical material (1 Macc 7:1-4) is one of those texts that describe an event happening far away from the scope of influence exerted by the Maccabean insurgents, yet one which is closely connected with the history of the chosen people. As such, it substantially influences the successive events in the political-religious situation of the Jews. What is particularly worthy of analysis is the historical accuracy of the inspired author in presenting facts as well as the theological conception to which primary importance is given in the book. This way the history of peoples, kingdoms and societies is shown as part of God's magnificent plans which is implemented by all participants of ongoing scenes. Such a presentation concerns both the main and supporting protagonists. The short passage of 1 Macc 7:1-4 reveals how the hagiographer, who knows the theological conception, consciously accentuates certain parts, chooses appropriate syntax and vocabulary to show God's action in the presented characters and events. God stands behind the curtain of human actions, yet it is Him who decides about their course.

\section{Keywords}

biblical exegesis, Septuagint, the First Book of Maccabees, Demetrius I Soter, Maccabean revolt 


\section{Bibliography}

Allen L. C., Ezekiel 20-48, Word Biblical Commentary 29, Dallas 1990.

Allen L. C., Jeremiah. A Commentary, Old Testament Library, Louisville-London 2008. Ancient Earthquakes, ed. M. Sintubin et al., Special Paper 471, The Geological Society of America, Boulder 2010.

Appian, Roman History 11: The Syrian Book, Vol. 3, trans. B. McGing, Loeb Classical Library (=LCL) 4, Cambridge (MA) 2019.

Badian E., Foreign Clientelae (264-70 BC), Oxford-New York 2000.

Bar-Kochva B., Judas Maccabaeus: The Jewish Struggle Against the Seleucids, Cambridge 1989.

Bederman D. J., International Law in Antiquity, Cambridge-New York 2001.

Block D. I., The Book of Ezekiel. Chapters 1-24, New International Commentary on the Old Testament, Grand Rapids-Cambridge 1997.

Bourguet D., Des métaphores de Jérémie, Études Bibliques 9, Paris 1987.

Breneman M., Ezra - Nehemiah - Esther. An Exegetical and Theological Exposition of Holy Scripture, New International Version - New American Commentary 29, Nashville 1993.

Briant P., Histoire de l'Empire perse, de Cyrus à Alexandre, Paris 1996.

Burton P. J., Friendship and Empire: Roman Diplomacy and Imperialism in the Middle Republic (353-146 BC), Cambridge 2011.

Bush F., Ruth/Esther, Word Biblical Commentary 9, Dallas 1996.

Capdetrey L., Le pouvoir séleucide. Territoire, administration, finances d'un royaume hellénistique (312-129 avant J.-C.), coll. "Histoire", Rennes 2007.

Champion C. B., Cultural Politics in Polybius's Histories, Berkeley-Los Angeles-London 2004.

Clines D. J. A., Job 1-20, Word Biblical Commentary 17, Dallas 1989.

Cooper Sr. L. E., Ezekiel. An Exegetical and Theological Exposition of Holy Scripture, New International Version - New American Commentary 17, Nashville 1994.

DeVries S. J., 1 Kings, Word Biblical Commentary 12, Waco 1985.

Dictionnaire de la civilisation phénicienne et punique, ed. E. Lipiński, Turnhout 1992.

Dillon M., Garland L., Ancient Rome: A Sourcebook, Abingdon 2005.

Diodorus Siculus, Library of History, Vol. 7: Books 15.20-16.65, trans. C. L. Sherman, Loeb Classical Library 389, Cambridge (MA) 1952.

Doran R., The first book of Maccabees, in: The New interpreter's Bible, ed. L. E. Keck, D. L. Petersen, Vol. 4, Nashville 1996.

Duyrat F., Arados hellénistique. Étude historique et monétaire, Beyrouth 2005.

Eckstein A. M., Moral Vision in the Histories of Polybius, Berkeley-Los Angeles-London 1995. 
Gauthier P., Les cites hellénistiques: épigraphie et histoire true colorsdes institutions et des régimes politiques, in: Actes du VIII Congrès International d'Épigraphie Grecque et Latine, Athènes, 3 - 9 octobre 1982, Athènes 1984, pp. 82-107.

Gera D., Judaea and Mediterranean Politics: 219 to 161 B.C.E., Leiden-New YorkKöln 1998.

Goldstein J. A., I Maccabees. A New Translation with Introduction and Commentary, The Anchor Bible 41, Garden City 1976.

Hayes J. H., Mandell S., The Jewish People in Classical Antiquity: From Alexander to Bar Kochba, Louisville-London-Leiden 1998.

House P. R., 1,2 Kings. An Exegetical and Theological Exposition of Holy Scripture, New International Version - New American Commentary 8, Nashville 1995.

Howard Jr. D. M., Joshua. An Exegetical and Theological Exposition of Holy Scripture, New International Version - New American Commentary 5, Nashville 1998.

Huey Jr. F. B., Jeremiah, Lamentations. An Exegetical and Theological Exposition of Holy Scripture, New International Version - New American Commentary 16, Nashville 1993.

International Dictionary of Historic Places, Vol. 4: Middle East and Africa, ed. T. Ring, N. Watson, P. Schellinger, Chicago 1996.

Johnson A. C., Coleman-Norton P. R., Bourne F. C., Ancient Roman Statutes: A Translation with Introduction, Commentary, Glossary and Index, Austin 1961.

Josephus, Jewish Antiquities, Vol. 5: Books 12-13, trans. R. Marcus, Loeb Classical Library 365, Cambridge (MA) 1943.

Księga Estery z komentarzem Malbima, Kraków 2004.

Livy, Julius Obsequens, History of Rome, Vol. 14: Summaries. Fragments. Julius Obsequens. General Index, trans. A. C. Schlesinger, Loeb Classical Library 404, Cambridge (MA) 1959.

Long G., The Decline of the Roman Republic, Vol. 3, London 1869.

Ma J., Antiochos III and the Cities of Western Asia Minor, Oxford 1999.

Morby J. E., Dynastie świata. Przewodnik chronologiczny i genealogiczny, tł. M. Rusinek, Kraków 1998.

Mørkholm O., Early Hellenistic Coinage. From the accession of Alexander to the peace of Apamea (336-188 B.C.), Cambridge 2001.

Nawrot J., Kryzys religijny w Judei za Antiocha IV Epifanesa. Teologia historii w 1 Mch 1,1-2,26, Poznań 2012.

Nawrot J., Pierwsza Księga Machabejska. Rozdziały 6,17-16,24, Nowy Komentarz Biblijny - Stary Testament XIV/II, Częstochowa 2020.

Nicolet C., Rome et la conquête du monde méditeranéen: 264-27 avant J.-C., Vol. 2: Genèse d'un empire, Paris 2004.

Picard O., Callataÿ de F., Duyrat F., Gorre G., Prévot D., Royaumes et cités hellénistiques: de 323 à 55 av. J.-C., Lassay-les-Châteaux 2003. 
Polybius, The Histories. Books 28-39. Unattributed Fragments, Vol. 6, trans. W. R. Patton, rev. W. L. Walbank, C. Habicht, The Loeb Classical Library 161, Cambridge (MA) 2012.

Rappaport U., The Hellenistic World as Seen by the Book of Daniel, in: RASHI 1040-1990: Hommage à Ephraïm E. Urbach. IV Congrès européen des Études juives, ed. G. Sed-Rajna, Cerf, Paris 1993, pp. 71-79.

Rey-Coquais J.-P., Arados et sa pérée aux époques grecque, romaine et byzantine, Paris 1974.

Salamé-Sarkis H., Chronique archéologique du Liban-Nord. I. Fouilles d'El-Mina-Tripolis, "Bulletin du Musée de Beyrouth" 24(1971), pp. 91-102.

Sherwin-White S. M., Kuhrt A., From Samarkhand to Sardis: A New Approach to the Seleucid Empire, Berkeley-Los Angeles 1993.

Sweeney M. A., I \& II Kings. A Commentary, Old Testament Library, Louisville-London 2007.

Taylor M., Antiochus the Great, Barnsley 2013.

The New Complete Works of Josephus, trans. W. Whiston, Grand Rapids 1999.

Thompson J. A., The Book of Jeremiah, New International Commentary on the Old Testament, Grand Rapids 1980.

Vermeylen J., La maison de Saül et la maison de David, in: Figures de David à travers la Bible. XVII congrès de l'ACFÉtudes Bibliques: Lille, 1-5 septembre 1997, Association Catholique Française pour l'Étude de la Bible, Lectio Divina 177, Paris 1999.

Wipszycka E., Bravo B., Historia starożytnych Greków, t. 3: Okres hellenistyczny, Warszawa 2010.

Ziółkowski A., Historia Powszechna. Starożytność, Warszawa 2011. 